\title{
Reliabilitas test-retest dyer tennis test revision
}

\author{
Abdul Alim*, Risti Nurfadhila \\ Universitas Negeri Yogyakarta, Jalan Colombo Nomor 1 Yogyakarta, 55281, Indonesia. \\ * Coressponding Author. E-mail: abdulalim@uny.ac.id
}

Received: March 2, 2021; Revised: March 17, 2021; Accepted: April 27, 2021

\begin{abstract}
Abstrak: Banyak faktor yang mempengaruhi pencapaian prestasi olahraga, salah satu faktor yang mempengaruhi pencapaian prestasi pada cabang olahraga tenis lapangan adalah keterampilan dalam memukul bola. Instrumen tes yang valid dan reliabel diperlukan untuk mengetahui tingkat keterampilan pukulan untuk menentukan dan memantau hasil latihan. Tujuan penelitian ini adalah untuk mengetahui reliabilitas tes akurasi pukulan tenis lapangan menggunakan Dyer Tennis Test Revision. Pemilihan Dyer Tennis Test Revision sebagai intrumen tes pengukuran keterampilan akurasi pukulan tenis disesuaikan dengan subjek penelitian yaitu petenis pemula mahasiswa. Sembilan puluh tujuh mahasiswa pemula (51 laki-laki dan 46 perempuan) yang mengambil mata kuliah tenis lapangan menjadi subjek dalam penelitian ini. Test retest digunakan dalam penelitian ini. Hasil analisis product moment menunjukkan bahwa nilai $\mathrm{r}$ adalah 0,975. Hasil terebut bermakna bahwa Dyer Tennis Test Revision dapat diandalkan untuk mengukur unjuk kerja keterampilan tenis berbasis keakuratan. Dyer Tennis Test Revision juga merupakan alat ukur yang mudah dan murah yang dapat digunakan guru/dosen/pelatih untuk memantau kemajuan pemain.
\end{abstract}

Kata Kunci: Reliabilitas, tes, akurasi pukulan dan tenis lapangan

\section{Test-retest reliability for dyer tennis test revision}

Abstract: Many factors affect sports performance, one of the factors that affect performance in tennis is the skill in hitting the ball. A valid and reliable test instrument is needed to determine the skill level of the stroke to determine and monitor the results of the training. The purpose of this study was to determine the reliability of the hitting tennis accuracy test using the Dyer Tennis Test Revision. The choice of Dyer Tennis Test Revision as a test instrument for measuring the accuracy of tennis strokes was adjusted to the research subject, namely student novice tennis players. Ninety-seven (beginner students (51 male and 46 female) who took tennis court courses were the subjects in this study. The retest test was used in this study. The results of the product moment analysis show that the value of $r$ is 0.975. These results mean that the Dyer Tennis Test Revision can be relied upon to measure the performance of tennis skills based on accuracy. Dyer Tennis Test Revision is also an easy and inexpensive measuring tool that teachers / lecturers / coaches can use to monitor player progress.

Keywords: reliability, test, stroke accuracy and tennis

How to Cite: Alim, A., \& Nurfadhila, R. (2021). Reliabilitas test-retest dyer tennis test revision. Jurnal Keolahragaan, 9(1), 43-50. doi: https://doi.org/10.21831/jk.v9i1.39122

\section{PENDAHULUAN}

Tenis lapangan termasuk pada kategori cabang olahraga yang kompleks. Mayoritas pertandingan tenis lapangan memiliki rata-rata waktu pencapaian poin kurang dari 11 detik dengan waktu istirahat tidak lebih dari 25 detik (Ferrauti et al., 2001; König et al., 2001; O'Donoghue \& Ingram, 2001; Smekal et al., 2001; Kovacs, 2004; Kovacs et al., 2004; R.P Urso et.al, 2013). Berdasarkan pernyataan para ahli tersebut dapat dilihat bahwa dalam pertandingan tenis, atlet dituntut untuk melakukan aktivitas intensitas tinggi dalam waktu singkat kurang dari 11 detik dengan waktu pemulihan antar rally/point yang singkat pula yaitu kurang dari 25 detik. Selain itu, atlet juga mendapatkan waktu istirahat antar game (90 detik) dan antar set (120 detik). Pola permainan tersebut menunjukkan bahwa cabang olahraga tenis lapangan termasuk pada aktivitas intermitten. Karakteristik permainan tenis lapangan yang termasuk pada aktivitas intermitten, lama pertandingan yang tidak dapat diprediksi serta pukulan bola tenis yang cepat 
dan tidak tentu arah bolanya menjadikan atlet tenis harus benar-benar optimal pada kemampuan teknik, taktik, fisik maupun psikis.

Beberapa hasil penelitian menunjukkan bahwa panjang rally pada pertandingan tenis lapangan tingkat perguruan tinggi dan junior memiliki panjang waktu sekitar 9-13 detik (Danson, et.al 1991; Srecker, et.al 2004). Hal tersebut menunjukkan bahwa lamanya rally pada pertandingan tenis lapangan cukup konsisten. Dengan demikian menunjukkan bahwa penguasaan keterampilan teknik tenis lapangan sangat diperlukan dalam pertandingan tenis lapangan. Penguasaan teknik pukulan tenis yang bagus akan dapat membantu konsistesi pukulan petenis saat bermain. Keterampilan dan teknik tenis lapangan yang telah berkembang dengan baik merupakan parameter penting untuk pengenalan bakat.

Dalam permainan tenis lapangan kinerja teknik dan taktik merupakan hal yang sangat penting Meylan et al., 2010, p.573). Teknik dalam tenis lapangan dicirikan dengan kulaitas pukulan yang cepat dan memiliki akurasi yang baik dan konsisten (Landlinger et al., 2012, p.304). Kemampuan bermain tenis akan meningkat apabila teknik pukulan dasar dikuasi dengan baik sebagai landasan pengembangan teknik dan taktik tingkat lanjut (Nurfadhila, p. 198). Penguasaan teknik pukulan dalam tenis lapangan sangat diperlukan untuk melancarkan taktik yang sesuai pada situasi tertentu. Akibatnya, saat keterampilan teknik pukulan tenis berkembang maka kualitas kemampuan taktik juga akan dapat meningkat (Wang et al., 2013). Kemampuan taktik dalam tenis lapangan didefinisikan sebagai kemampuan untuk beradaptasi dalam pertandigan atau game dan aktivitas pengambilan keputusan di lapangan saat bertanding (Elferink- Gemser et al., 2010, p. 521). Tindakan antisipasi terhadap pukulan lawan bersama dengan pengambilan keputusan yang tepat merupakan aspek penting dari kinerja taktik yang sukses. Atlet tenis yang memiliki penguasaan teknik dan taktik yang baik akan dapat mencapai peforma yang baik pula tentunya didukung oleh faktor kondisi fisik dan psikis. Pemain profesional memiliki lebih banyak pengalaman atau jam terbang dalam pengambilan keputusan pada tindakan yang akan dilakukan dalam rangka mengantisipasi pukulan lawan daripada petenis pemula (Williams et al., 2002, p. 261). Lebih lanjut Williams dkk. (2002) menerangkan bahwa pemain profesional mengantisipasi lawan mereka lebih baik dan membuat keputusan lebih awal daripada pemula, yang merupakan keuntungan substansial untuk eksekusi groundstrokes. Crognier dan Féry (2005, p.637) menunjukkan bahwa antisipasi pukulan tergantung dari situasi taktik (yaitu ofensif, netral dan defensif). Mereka menunjukkan bahwa akurasi petenis dalam mengantisipasi arah gerak mencegah bola mendekati $80 \%$ saat petenis berada dalam situasi ofensif, sedangkan keakuratannya lebih rendah saat berada dalam situasi defensif.

Dengan menguasai teknik tenis lapangan yaitu groundstroke, service, overhead dan volley maka seseorang tersebut dikatakan dapat bermain tenis (Larry, 1998; Patrick, 1998). Penguasaan yang baik dalam teknik merupakan hal yang mutlak bagi atlet tenis lapangan, karena atlet tidak hanya memukul bola satu atau dua kali saja, namun akan memukul bola sepanjang permainan berlangsung, sehingga atlet tenis lapangan harus dapat menjaga konsistensi dalam melakukan pukulan yang akurat selama pertandingan berlangsung. Dari beberapa teknik yang ada dalam tenis lapangan, groundstroke merupakan salah satu pukulan yang paling sering/ banyak digunakan sepanjang pertandingan (Zuqing, et al, 2015, p.1058). Penguasaan terhadap teknik groundstroke, dapat digunakan dalam posisi bertahan dan menyerang. Atlet tenis lapangan dapat melakukan groundstroke dari baseline untuk menciptakan peluang menyerang pertahanan lawan dengan cara memukul bola ke arah yang sulit dijangkau lawan. Berdasarkan pernyataan yang sudah disampaikan dapat disimpulkan bahwa pengusaan teknik groundstroke merupakan hal yang penting dan wajib bagi atlet tenis lapangan untuk dapat mendukung pencapaian peforma yang optimal.

Groundstroke yang baik adalah groundstroke yang konsisten akurasinya dan nilai tambah apabila bola yang dihasilkan dari groundstroke tersebut dapat melaju dengan cepat. Terdapat beberapa penelitian yang meneliti mengenai groundstroke. Kraemer et. al melakukan beberapa tes dengan subjek penelitian menggunakan atlet tenis junior perempuan. Hasil penelitian tersebut menunjukkan bahwa kelemahan pada sendi dan kemampuan kekuatan yang dikuasai atlet memiliki hubungan dengan kecepatan bola (Triplett, et al. 1995). Hasil Keterampilan bermain tenis memainkan peran utama dalam produksi kecepatan bola (Perry et. a., 2004). Penelitian lain juga menunjukkan bahwa atlet tenis lakilaki dan perempuan dengan kekuatan isokinetik terbesar menunjukkan kecepatan pukulan bola yang paling cepat, selain itu atlet tenis dengan kecepatan bola tercepat memiliki kesulitan dalam penempatan dan akurasi bola. Oleh karena itu, akurasi lebih penting dibandingkan dengan kecepatan bola karena dengan peningkatan kecepatan bola dimungkinkan adanya penurunan akurasi dan peningkatan jumlah 
kesalahan. Diperlukan latihan yang benar, terukur dan berkelanjutan untuk dapat memiliki keterampilan groundstroke yang baik sehingga dapat menghasilkan pukulan yang konsisten akurasinya dan dapat melaju dengan cepat.

Akurasi dalam tenis lapangan diartikan sebagai hasil pukulan yang dapat mengarahkan bola kepada satu titik sasaran tertentu yang sudah ditentukan di lapangan. Bola yang dipukul akan selalu mengarah pada target yang dituju.Terdapat beberapa penelitian yang meneliti mengenai akurasi pukulan pada tenis lapangan. Davey et.al memiliki 18 pemain tenis (9 pria dan 9 wanita) melakukan 2 tes keterampilan pada 2 kesempatan berbeda (Davey et.al., 2002). Peserta melakukan 2 latihan 20 bola secara bergantian forehand dan backhand (10 untuk setiap sisi) memukul ke area yang telah ditentukan $(1,5 \mathrm{~m} 2)$. Hasil menunjukkan tidak ada perbedaan antara tes untuk forehand dan backhand untuk crosscourt (CC) dan down line (Davey et.al, 2002). Ferrauti dkk. (2001, p.235) juga menguji akurasi pukulan pada pemain tenis lapangan setelah subjek melakukan 240 menit permainan pertandingan tunggal. Para pemain tenis tersebut diminta untuk melakukan uji akurasi pukulan dengan mesin bola ke area seluas 1,5 dan $3 \mathrm{~m}^{2}$. Salah satu masalah dengan protokol ini adalah bahwa area target terbesar hanya mencakup sebagian kecil dari lapangan tenis tersebut, karena total luas lapangan tenis tunggal adalah $97,8 \mathrm{~m} 2$. Penelitian tersebut menunjukkan beberapa permasalahan yang dihadapi di lapangan, sehingga diperlukan instrumen tes yang tepat dan konsisten dalam mengukur kemampuan yang ingin dikukur.

Instrumen tes yang baik adalah instrumen tes yang dapat mengukur secara tepat dan konsisten, sehingga kemampuan orang yang dites betul-betul berada pada kategori yang sesungguhnya. Pengembangan sebuah instrumen tes dapat mengahasilkan instrumen tes yang layak untuk digunakan harus memiliki syarat valid dan reliabel (Widhiarso, 2010, p.1). Kebutuhan akan intrumen tes juga diperlukan pada mata kuliah olahraga pilihan tenis lapangan untuk mengukur hasil pembelajaran. Mata kuliah tenis lapangan merupakan salah satu mata kuliah olahraga pilihan yang ditawarkan oleh Program Studi Sarjana Pendidikan Kepelatihan Olahraga (PKO) Fakultas Ilmu Keolahraggan Universitas Negeri Yogyakarta. Mahasiswa yang mengikuti perkuliahan tersebut merupakan mahasiswa yang mayoritas termasuk dalam kategori pemula, sehingga instrumen tes yang digunakan seharusnya adalan tes khusus bagi pemula dewasa.

Terdapat beberapa instrumen pengukuran yang digunakan untuk mengukur keterampilan pukulan tenis. Masing-masing instrumen memiliki sepesifikasi subjek maupun karakter prosedur yang berbeda-beda. Salah satu intrumen yang digunakan untuk mengukur kemampuan akurasi pukulan adalah Dyer Tennis Test. Dyer Tennis Test ini sudah digunakan sejak tahun 1935 oleh guru pendidikan jasmani dan pelatih untuk tujuan klasifikasi (Jack, 1965, p. 153). Tes ini mengalami beberapa kali revisi karena dianggap tidak mampu untuk menilai atau membedakan peringkat dari kemampuan tenis lapangan. Revisi yang dilakukan oleh Jack Hewitt terhadap Dyer Tennis Test melalui poses penelitian dan pengembangan. Hasil revisi tersebut menghasilkan tes keterampilan tenis lapangan yang valid, reliabel dan efektif untuk mengukur keterampilan tenis lapangan pemula. Oleh karena itu, penelitian ini bertujuan untuk mengetahui konsitensi Dyer Tennis Test Revision dalam mengukur keterampilan tenis lapangan mahasiswa.

\section{METODE}

Desain penelitian yang digunakan adalah deskriptif kuantitatif. Tujuan dari penelitian ini adalah untuk mengetahui reliabilitas tes akurasi pukulan tenis lapangan Dyer Tennis Test Revision. Untuk menyelesaikan semua prosedur pengujian, seluruh peserta diminta untuk memberikan persetujuan kesediaan untuk menjadi subjek penelitian.

Teknik purposive sampling digunakan dalam penelitian ini dengan kriteria sebagai berikut: a) Mahasiswa S1 PKO yang aktif mengikuti perkuliahan olahraga pilihan tenis, b) bersedia menjadi subjek pada penelitian ini, c) sehat dan tidak dalam kondisi cedera, serta d) mengikuti dua kali Dyer Tennis Test Revision. Sembilan puluh tujuh (51 orang laki-laki dan 46 orang perempuan) mahasiswa menjadi subjek penelitian ini. Seluruh subjek penelitian merupakan pemula dewasa di cabang olahraga tenis lapangan.

Seluruh subjek penelitian ini diminta untuk melakukan Dyer Tennis Test Revision yang merupakan revisi Dyer Tennis Test oleh Hewitt. Peralatan dan perlengkapan yang diperlukan dalam pelaksanaan tes ini meliputi: 1) dinding atau papan yang memiliki permukaan datar atau halus dengan tinggi $20 \mathrm{ft}(6,096 \mathrm{~m})$ dan lebar $20 \mathrm{ft}(6,096 \mathrm{~m}) ; 2)$ Meteran untuk mengukur sasaran yang digunakan 
pada tes; 3) selotip atau kapur untuk memberi tanda pada sasaran (tinggi: 20ft, lebar: 20ft, dan jarak tinggi sasaran dengan lantai: $3 \mathrm{ft}(0,914 \mathrm{~m})$ ) dan jarak tempat memukul bola dengan sasaran yaitu $20 \mathrm{ft}$ $(6,096 \mathrm{~m})$; 4) keranjang bola dan bola tenis; 5) raket tenis, 6) stopwatch, dan 7) lembar skor dan pensil/ballpoint untuk mencatat hasil tes.

Pelaksanaan tes harus sesui dengan prosedur. Prosedur Dyer Tennis Test Revision diawali dengan pemanasan. Sebelum melakukan tes, subjek penelitian memulai dengan 15 menit pemanasan dinamis yang diikuti 5 menit pemanasan teknik melakukan rally dengan partner. Setelah selesai melakukan pemanasan, secara bergantian subjek penelitian melakukkan tes. Subjek penelitian memulai tes dengan menempatkan diri pada garis batas memukul yaitu $20 \mathrm{ft}$ dari sasaran (dinding/papan). Cadangan bola ditempatkan disamping belakang subjek penelitian. Tes dimulai dengan melakukan servis dari belakang garis batas memukul (semua jenis servis diperbolehkan). Ketika bola menyentuh sasaran, maka stopwatch dimulai. Apabila subjek penelitian kehilangan bola saat rally pertama maka dapat dilanjutkan dengan menggunakan bola lainnya. Setiap awal melakukan pukulan diharuskan melakukan serve dari belakang garis batas. Subjek penelitian melakukan rally dengan sasaran selama 30 detik. Tes tersebut dilakukan dua kali putaran selama perkuliahan.

Perhitungan skor pada Dyer Tennis Test Revision dilakukan dengan ketentuan sebagai berikut: 1) satu poin dihitung setiap kali bola dipukul dan masuk pada sasaran (di atas garis net $3 \mathrm{ft}$ ); 2) bola yang menyentuh garis sasaran tetap mendapatkan poin; 3) rally yang tidak diawali dengan servis tidak akan dihitung poinnya; 4) bola yang dipukul oleh subjek penelitian di depan garis batas tidak mendapatkan poin; 5) bola yang tidak masuk sasaran atau di luar garis sasaran tidak mendapatkan poin.

Poin yang didapatkan oleh masing-masing subjek penelitian tersebut dijadikan sebagai data penelitian. Data disajikan dalam format statistik deskriptif. Data penelitian dianalisis menggunakan korelasi Pearson Product Moment untuk mengetahui reliabilitas (Wahyu Widhiarso, 2001, p.7). Analisis data dilakukan dengan menggunakan SPPSS.

\section{HASIL DAN PEMBAHASAN}

\section{Hasil}

Tujuan dari penelitian ini adalah untuk mengetahui reliabilitas test-retest dari tes akurasi groundstoke tenis lapangan. Pengambilan data keterampilan tenis lapangan menggunakan Dyer Tennis Test Revision dilakukan sebanyak dua kali oleh 97 orang subjek penelitian. Seluruh subjek penelitian mengikuti kedua tes yang dilaksanakan. Hasil penelitian ini diperoleh dari analisis data penelitian menggunakan analisis product moment. Berikut data penelitian yang didapatkan:

Tabel 1. Data Test-Retest

\begin{tabular}{clcccc}
\hline No. & Pengambilan Tes & Min & Max & Mean & SD \\
\hline 1. & I & 2 & 25 & 13,26 & 4,601 \\
2. & II & 3 & 25 & 14,59 & 4,420 \\
& rX1X2 & $\mathbf{0 , 9 7 5}$ & & & \\
\hline
\end{tabular}

Hasil penelitian menunjukkan bahwa poin minimal pada tes pertama adalah 2 dan poin minimal tes kedua adalah 3, sedangkan skor maksimal padat tes pertama dan kedua adalah sama yaitu 25 poin. Rata-rata poin dari tes pertama adalah 13,25, sedangkan pada tes ke dua adalah 14,59. Berdasarkan analisis data dengan menggunakan analisis product moment diketahui bahwa nilai $\mathrm{r}$ adalah 0,975. Berdasarkan standar rentangan norma koefisien reliabilitas, Dyer Tennis Test Revision termasuk pada kategori sangat bagus atau tinggi.

\section{Pembahasan}

Reliabilitas suatu intrumen tes merupakan hal yang sangat penting. Reliabilitas merupakan kemampuan suatu instrumen yang menunjukkan sejauh mana suatu ukuran menghasilkan angka atau skor yang sama setiap kali diberikan saat kontruksi yang diukur tidak berubah (Marlene et.al, 2007, p.96). Disebutkan pula olehWidhiarso bahwa reliabilitas berfungsi untuk menunjukkan kosistensi tes sehingga dapat meningkatkan kualitas instrument tes (Tomoliyus, 2019 p.150). Terdapat berbagai macam jenis uji reliabilitas. Implementasi uji reliabilitas disesuaikan dengan kondisi atau kebutuhan instrument tes yang akan diuji reliabilitasnya. Pada penelitian ini uji reliabilitas menggunakan testretest. Masing-masing subjek penelitian melakukan tes yang sama sebanyak dua kali. Perhitungan 
reliabilitas pada test-retest dilakukan dengan cara mengkorelasikan hasil pengkuran tes pertama dan kedua.

Berdasarkan hasil analisis data yang telah dilakukan didapatkan nilai $r$ sebesar 0,975. Koefisien reliabilitas berkisar 0 hingga 1, dengan 0,7 ambang standar untuk keandalan yang memadai bagi perbandingan kelompok dan ambang minimum yang lebih ketat bagi individu sebasar 0,90 (Marlene et.al, 2007, p.96). Hal ini berarti bahwa Dyer Tennis Test Revision memiliki nilai koefisien reliabilitas sangat bagus/ sangat tinggi. Hasil tes tersebut menunjukkan bahwa Dyer Tennis Test Revision memiliki konsistensi yang tinggi dalam mengukur kemampuan keterampilan pukulan tenis Mahasiswa mata kuliah olahraga pilihan tenis lapangan. Reliabilitas sangat penting untuk diketahui dalam suatu tes. Secara umum, reliabilitas merupakan prasyarat utama dalam penerapan tes karena mengindikasikan kesalahan pengujian, sehingga dengan mengetahui reliabilitas akan diketahui konsistensi kebenaran pada tes tersebut (Bellar et al., 2015; Waldron et al., 2014).

Beberapa instrumen tes yang ada di cabang olahraga tenis lapangan diketahui reliabilitasnya dengan menggunakan test-retest. Penelitian yang dilakuan oleh Strecker et.al (2011) mengenai testretest reliability for hitting accuracy tennis test. Penelitian ini bertujuan untuk menilai reliabilitas testretest dari tes akurasi pukulan tenis "hitting accuracy tennis test" (HATT) dengan subjek penelitian adalah atlet nasional divisi I pada National Collegiate Athletic Association (NCAA) sebanyak 12 pemanin tenis. Hasil penelitian menunjukkan bahwa HATT memiliki reliabilitas yang baik bagi atlet tenis terlatih untuk mengukur kinerja keterampilan tenis berdasarkan keakuratan.

Penelitian lain yang dilakukan oleh Sekulic et.al (2017) mengenai reliabilitas dan validitas faktorial tes kelincahan non spesifik dan spesifik tenis lapangan. Tujuan dari penelitian ini adalah untuk mengevalusi reliabilitas dan validitas faktorial dari tes kelincahan non spesifik (tanpa raket tenis) dan spesifik tenis lapangan (dengan raket tenis). Sampel penelitian ini terdiri dari 33 atlet tenis lapangan. Kaitannya dengan uji reliabilitas, penelitian ini menggunakan Pearson's product moment correlations. Hasil penelitian menunjukkan bahwa nilai $r$ untuk tes kelincahan spesifik adalah 0.93 dan non-spesifik adalah 0,98 .

Penelitian mengenai reliabilitas dari tes keterampilan tenknik dilakukan oleh Slosar et.al pada tahun 2019. Tujuan dari penelitian ini adalah untuk membuat skala penilaian yang valid dan reliabel untuk mengevaluasi tiga pukulan dasar yaitu forehand, backhand dan serve untuk pemain tenis berusia 6-12 tahun yang diberi nama Tennis Score for Children (TRSC). Sejumlah 60 petenis menjadi subjek penelitian ini. Analisis data yang digunakan adalah intra class coeficcient (ICC). Hasil penelitian menunjukkan bahwa reliabilitas tes dangat tinggi.

Berdasarkan tiga penelitian terdahulu yang sudah dijelaskan dapat diketahui bahwa test-retest merupakan analisis data yang handal dalam menilai atau mengukur reliabilitas suatu tes. Selain itu, dari ketiga penelitian terdahulu tersebut dapat dicermati bahwa setiap tes memiliki teknik analisis data masing-masing sesuai dengan kebutuhan. Masing-masing tes juga memiliki spesifikasi subjek. Tes untuk atlet profesional akan berbeda dengan tes yang diterapkan pada petenis anak-anak maupun pemula dewasa. Dapat dilihat pada penelitian yang dilakukan oleh Strecker et.al instrument tes yang digunakan adalah "hitting accuracy tennis test" (HATT) dengan kekhususan penggunaan untuk atlet tenis lapangan profesional. Tennis Score for Children dikembangkan oleh Slosar et.al untuk mengukur keterampilan pukulan petenis anak-anak, sedangkan Dyer tennis tes revision merupakan salah satu tes keterampilan akurasi pukulan dengan subjek petenis pemula tingkat perguruan tinggi. Hal ini diperkuat oleh hasil penelitian Jack Hewitt mengenai revisi dari Dyer Tennis Test yang menunjukkan bahwa Dyer Tennis Test versi orisinal tidak cukup membedakan keterampilan di tingkat pemula. Berdasarkan kebutuhan dan jenis data, penelitian ini menggunakan teknik analisis product moment karena menggunakan teknik tes retest.

Dalam penelitian yang dilakukan oleh Jack Hewitt dijelaskan bahwa Dyer pertama kali melaporkan tes pada tahun 1935 dan melakukan sedikit revisi pada tahun 1938. Dalam tes versi orisinal, Dyer meminta siswa untuk memukul bola ke arah sasaran dan melalukan rally sendiri menggunakan groundstroke atau volley untuk batas waktu 30 detik. Bola harus dipukul dengan raket tenis di atas garis $3 \mathrm{ft}$ di dinding yang merepresentasikan net dan skor total adalah jumlah pukulan yang memantul pada kotak sasaran yang dilakukan selama 30 detik. Dyer memvalidasi skor dyer test dengan membandingkan penilaian tiga ahli tenis lapangan yang membuat penilaian pada siswa yang bermain permainan tenis.

Dyer merevisi tes aslinya pada tahun 1938 dengan menambahkan garis start $5 \mathrm{ft}$ dari sasaran. Garis start tersebut ditambahkan untuk mencegah siswa berdiri dekat dengan tembok. Siswa 
menemukan bahwa mereka dapat memperoleh skor yang lebih tinggi dengan mengeliminasi sebagian besar groundstroke dan mendekati dinding untuk melakukan pukulan volley. Oleh karena itu, jumlah poin yang didapat tidak dapat mengambarkan tingkat keterampilan pukulan tenis lapangan. Pada tahun 1953 Fox, dalam studinya tentang validitas Dyer Tennis Test, menyimpulkan bahwa Dyer Tennis Test tidak cukup mendiskriminasi untuk menunjukkan peringkat yang berbeda dari kemampuan tenis lapangan.

Jack Hewitt, pada tahun 1963, memberikan Dyer Tennis Test kepada beberapa mahasiswa yang mengambil mata kuliah tenis lapangan di University of California, Riverside. Ketika Dyer Tennis Test dibandingkan dengan urutan peringkat permainan (urutan peringkat ditentukan oleh turnamen tenis round robin) keseluruhan nilai korelasi cukup rendah dan tidak signifikan. Hasil ini secara umum setuju dengan penelitian yang dilakukan oleh Fox sebelumnya.

Jack Hewitt pada semester yang sama tahun 1963, memberikan Dyer Tennis Test kepada dua kelas lanjutan (40 siswa yang memiliki lebih dari satu semester mengikuti mata kuliah tenis lapangan) dan membandingkan nilai Dyer Tennis Test dengan urutan peringkat pertandingan. Hubungan antara urutan peringkat pertandingan dan Dyer Tennis Test menunjukkan Rho dan $\mathrm{r}$ yang sesuai masing-masing 0,77 dan 0,70, Hal ini menunjukkan bahwa Dyer Tennis Test memiliki korelasi yang lebih tinggi pada petenis tingkat mahir. Penjelasan yang mungkin didasarkan pada fakta bahwa Dyer Tennis Test paling baik mengukur keterampilan tenis lanjutan voli karena siswa dapat mencapai jarak 5 kaki dari papan belakang. Mayoritas ahli setuju bahwa pukulan volley bukanlah keterampilan yang diperlihatkan oleh kebanyakan siswa pemula dalam tenis. Oleh karena itu, tes yang dapat digunakan untuk menilai keterampilan memukul (akurasi) bagi petenis pemula adalah Dyer Tennis Test Revision. Kesimpulan ini juga didukung dengan hasil analisis data product moment yang menunjukkan nilai $r$ adalah 0,975. Berdasarkan standar rentangan norma koefisien reliabilitas, Dyer Tennis Test Revision termasuk pada kategori sangat bagus atau tinggi dengan subjek penelitian petenis pemula tingkat mahasiswa.

\section{SIMPULAN}

Terdapat beberapa faktor yang mempengaruhi peforma seseorang dalam bermain tenis lapangan. Faktor-faktor tersebut meliputi: teknik, taktik, kondisi fisik, dan psikis atau mental. Penguasaan teknik merupakan salah satu keterampilan yang harus dikuasai karena dengan penguasaan keterampilan yang baik hasil gerak yang dilakukan dapat efektif dan efisien. Penempatan bola yang dilakukan oleh petenis dapat membantu dalam perolehan poin. Oleh karena itu, petenis harus memiliki kemampuan akurasi pukulan yang baik. Untuk mengetahui kemampuan akurasi pukulan tenis lapangan pada petenis pemula dewasa dapat menggunakan Dyer Tennis Test Revision.

Berdasarkan hasil analisis data dapat disimpulkan bahwa Dyer Tennis Test Revision memiliki nilai koefisien reliabilitas sangat tinggi. Hasil tes tersebut menunjukkan bahwa Dyer Tennis Test Revision memiliki konsistensi yang tinggi untuk mengukur kemampuan keterampilan pukulan tenis lapangan petenis pemula mahasiswa (mahasiswa yang mengkuti mata kuliah olahraga pilihan tenis lapangan). Dyer Tennis Test Revision memiliki kapabilitas untuk mendiskriminasikan keterampilan pukulan tenis lapangan.

Jarak garis batas memukul bola dengan sasaran sejauh $20 \mathrm{ft}$ pada Dyer Tennis Test Revision memberikan kesempatan kepada mahasiswa (subjek penelitian) melakukan berbagai jenis pukulan, tidak hanya pukulan volley saja, sehingga kemampuan mengarahkan bola dapat ditampilkan dan diukur. Oleh karena itu, dalam penilaian kemampuan akurasi pukulan mahasiswa sebagai evaluasi pembelajaran atau pelatihan direkomendasikan menggunakan Dyer Tennis Test Revision. Dalam upaya kelancaran pelaksanaan Dyer Tennis Test Revision disarankan pada saat pelaksanaan menugaskan dua orang dengan rincian sebagai berikut: satu orang sebagai timer, satu orang sebagai penghitung poin dan bertugas melihat pergerakan kaki supaya terdeteksi apabila kaki testee melewati garis batas.

\section{DAFTAR PUSTAKA}

Bellar D, Marcus L, Judge LW. (2015). Validation and Reliability of a Novel Test of Upper Body Isometric Strength. J Hum Kinet; 47: 189-195. doi: 10.1515/hukin-2015-0074

Crognier L, Féry YA.(2005). Effect of tactical initiative on predicting passing shots in tennis. Appl Cognitive Psych,19: 637-649. 
Danson, P, Chirpaz-Addou, MF, Gharib, C, and Quirion, A.(1991). Hormonal and metabolic changes during a strenuous tennis match. Effect of ageing. Int J Sports Med, 12: 10-16.

Davey, PR, Thorpe, RD, and Williams, C. (2002) Fatigue decreases skilled tennis performance. $J$ Sports Sci, 20: 311-318.

Elferink-Gemser MT, Kannekens R, Lyons J, Tromp Y, Visscher C. (2010). Knowing what to do and doing it: Differences in self-assessed tactical skills of regional, sub-elite, and elite youth field hockey players. J Sport Sci, 28: 521-528

Ferrauti, A, Pluim, BM, and Weber, K. (2001). The effect of recovery duration on running speed and stroke quality during intermittent training drills in elite tennis players. J Sports Sci 19: 235242.

Ferrauti A., Pluim B.M., Busch T., Weber K. (2003). Blood glucose responses and incidence of hypoglycaemia in elite tennis under practice and tournament conditions. Journal of Science and Medicine in Spor 6, 28-39.

Jack E. Hewitt. (1965). Revision of the Dyer Backboard Tennis Test, Research Quarterly. American Association for Health, Physical Education and Recreation, 36:2, 153-157.

König D., Huonker M., Schmid A., Halle M., Berg A., Keul J. (2001). Cardiovascular, metabolic, and hormonal parameters in professional tennis players. Medicine and Science in Sports and Exercise, 33, 654-658.

Kovacs M S. (2004). A comparison of work/rest intervals in men's professional tennis. Medicine and Science in Tennis, 9, 10-11.

Kovacs M.S., Strecker E., Chandler W.B., Smith J.W., Pascoe D.D. (2004). Time analysis of work/rest intervals in men's collegiate tennis. Journal of Strength and Conditioning Research, 18, e364.

Landlinger J, Stöggl T, Lindinger S, Wagner H, Müller E. (2012). Differences in ball speed and accuracy of tennis groundstrokes between elite and high-performance players. Eur J Sport Sci, 12: $301-308$

Larry Hansley. (1998). "Tennis Skill Test Manual". American Alliance for Health, Physical Education, Recreation and Dance.

Marlene, H.F; Bryce B.R; Astra M.L.P; Josep W.S \& Ron D. (2007). What Is Sufficient Evidence for the Reliability and Validity of Patient-Reported Outcome Measures?. Value in Health, 10 (2), p. S94-S105.

Meylan C, Cronin J, Oliver J, Hughes M. (2010) Reviews: Talent identification in soccer: The role of maturity status on physical, physiological and technical characteristics. Int J Sports Sci Coach, 5: 571-592

Nurfadhila, Risti. Pengaruh latihan imagery dan koordinasi terhadap keterampilan forehand drive petenis pemula. Jurnal Keolahragaan, [S.1.], v. 4, n. 2, p. 196 - 206, sep. 2016. ISSN24610259.https://journal.uny.ac.id/index.php/jolahraga/article/view/10898/8529. 23 apr. 2021. doi:https://doi.org/10.21831/jk.v4i2.10898.

O'Donoghue P., Ingram B. (2001). A notational analysis of elite tennis strategy. Journal of Sports Sciences. 19, 107-115.

Patrick McEnroe and Peter Bodo. (1998). Tennis for Dummies. Willey Publishing. Inc, Indiana Polis, Indiana.

Perry, A.C., X. Wang, B.B. Feldman, T. Ruth, and J. Signorile. (2004). Can laboratory-based tennis profiles predict field tests of tennis performance? J. Strength Cond. Res. 18(1):136- 143.

Sekulic, D., Uljevic, O., Peric, M., Spasic, M., \& Kondric, M. (2017). Reliability and factorial validity of non-specific and tennis-specific pre-planned agility tests; preliminary analysis. Journal of Human Kinetics, 55(1), 107-116. https://doi.org/10.1515/hukin-2017-0010.

Šlosar, L., Šimunič, B., Pišot, R., \& Marusic, U. (2019). Validation of a Tennis Rating Score to evaluate the technical level of children tennis players. Journal of Sports Sciences, 37(1), 100107. https://doi.org/10.1080/02640414.2018.1483184 
Smekal G., Von Duvillard S.P., Rihacek C.N., Pokan R., Hofman P., Baron R., Tschan H., Bachl N. (2001). A physiological profile of tennis matchplay. Medicine and Science in Sports and Exercise, 33, 999-1005.

Strecker, E, Chandler, B, Smith, JE, and Pascoe, DD. (2004). Time Analysis of Work/Rest Intervals in Men's Professional Tennis. Atlanta, GA: South East ACSM.

Strecker, E., Foster, E. B., \& Pascoe, D. D. (2011). Test-retest reliability for hitting accuracy tennis test. Journal of Strength and Conditioning Research, 25(12), 3501-3505. https://doi.org/10.1519/JSC.0b013e318215fde6

Tomoliyus \& Sunardiant, R. Validitas dan reliabilitas instrumen tes reaktif agility tenis meja. Jurnal Keolahragaan, [S.1.], v. 8, n. 2, p. 148-157, aug. 2020. ISSN 2461-0259. https://journal.uny.ac.id/index.php/jolahraga/article/view/32492/14838, doi:https://doi.org/10.21831/jk.v8i2.32492.

Triplett, NT, Fry, AC, Koziris, LP, Bauer, JA, Lynch, JM, Mcconnell, T, Newton, RU, Gordon, SE, Nelson, R C, and Knuttgen, HG. (1995). An in-depth sports medicine profile of women college tennis players. J Sports Rehab, 4: 79-98.

Urso RP, et al. (2013). Validity and reliability evidences of the Hit \& Turn Tennis Test. Sci sports, http://dx.doi.org/10.1016/j.scispo.2013.06.006.

Wahyu Widhiarso. (2001). SPSS untuk Psikologi. Yogyakarta: Fakultas Psikologi UGM

Waldron M, Worsfold P, Twist C, Lamb K. (2014). The reliability of tests for sport-specific skill amongst elite youth rugby league players. Eur J Sport Sci, 14: 471-477. doi: $10.1080 / 17461391.2012 .714405$

Wang MY, Liu YC, Chen CJ. (2013). Techniques and tactics analysis related to personality in tabletennisdoubles,Availableat:http://ittf.com/ittf_science/SSCenter/docs/Wang\%20M\%20Y_ Chen\%20C\%20J-1- revised-OK.pdf; accessed on 12.05.2016

Widhiarso, W. (2010). Melibatkan rater dalam pengembangan alat ukur. Yogyakarta: UGM

Williams AM, Ward P, Knowles JM, Smeeton NJ. (2002). Anticipation skill in a real-world task: measurement, training, and transfer in tennis. J Exp Psychol Appl, 8: 259-270 